\title{
Left vocal cord paralysis due to lymphadenopathy of mediastinal tuberculosis
}

\author{
Mediastinal tüberküloz lenfadenopatisine bağlı sol vokal kord paralizisi \\ Oğuzhan Dikici', Nuray Bayar Muluk² \\ ${ }^{\prime}$ Department of Otorbinolaryngology, Gaziantep Şehitkamil State Hospital, Gaziantep, Turkey \\ ${ }^{2}$ Department of Otorbinolaryngology, Faculty of Medicine, Kirıkale University, Kirlkkale, Turkey
}

\begin{abstract}
Though there are a lot of causes of vocal cord paralysis, such as trauma, cancer and surgery; idiopathic cases are also found. Vocal cord paralysis can be also seen in cases of mediastinal mass or tuberculosis which cause mediastinal lymphadenopathy. In this paper, a patient complaining of hoarseness with the diagnosis of left vocal cord paralysis was presented. Thoracic computed spiral tomography showed conglomerated mediastinal lymphadenopathy and biopsy was reported as granulomatous inflammation. Antituberculostatic therapy was administered to the patient and his follow-up procedures are continuing currently.
\end{abstract}

Key words: Vocal cord paralysis, tuberculosis, conglomerated mediastinal lymphadenopathy.

Vocal cord paralysis is a relatively common condition. Although larynx cancer and laryngeal trauma are the most obvious reasons, a variety of reasons other than the laryngeal conditions can cause vocal cord paralysis by affecting the branches of the recurrent laryngeal nerve (RLN). ${ }^{[1]}$

Unilateral vocal cord paralysis is a voice disorder detected by laryngoscopic examination. Trauma, cancer and surgery are the most common causes of vocal cord paralysis. Nevertheless some cases are associated with idiopathic causes. For this reason, in case of vocal cord paralysis, the actual effect should be observed in detail, evaluation and treatment should be performed as soon as possible. ${ }^{[2]}$

The majority of mediastinal masses are detected during radiological examinations performed for other complaints.

\begin{abstract}
Özet
Vokal kord paralizisinin travma, kanser ve cerrahi gibi sebepleri bulunmakla birlikte, idiyopatik vakalar da bulunmaktadır. Mediastinal kitle veya tüberküloz gibi mediastende lenfadenopatiye sebep olan durumlarda da vokal kord paralizi görülebilmektedir. Bu yazıda, ses kısıklığı şikâyeti ile başvuran ve sol vokal kord paralizisi tespit edilen bir vaka sunulmuştur. Hastada çekilen toraks bilgisayarlı tomografisinde (spiral) mediastende tespit edilen konglomere lenfadenopatiden alınan biyopsi sonucu, kazeifiye granülomatöz inflamasyon olarak rapor edilmiştir. Hastaya tüberküloz düşünülerek antitüberküloz tedavi başlanmıştır ve takipleri devam etmektedir.
\end{abstract}

Anahtar sözcükler: Vokal kord paralizisi, tüberküloz, mediastende konglomere lenfadenopati.

In symptomatic cases, nonspecific symptoms are found. Symptoms are the result of compression of adjacent structures by the mass and/or invasion. Thoracic computed tomography is quite useful for determining the location of mediastinal masses. ${ }^{[3]}$ In developing countries, involvement of mediastinal lymph nodes by tuberculosis is frequently seen, but the recurrent laryngeal nerve palsy and hoarseness due to tuberculosis are not common findings. ${ }^{[4]}$

\section{Case Report}

A 35-year-old female patient applied to Gaziantep Şehitkamil State Hospital, Ear, Nose and Throat polyclinic with complaints of feeling of fullness and obstruction in the throat persisting for 2 months. Flexible fiberoptic laryngo- 
scopic examinations performed in outpatient clinics showed left vocal cord paralysis, and left vocal cord was in a paramedian position. In the patient's history, there were no neck injury, neck surgery, or infection. On chest $\mathrm{X}$-rays, there was a left hilar mass which may be compatible with the left hilar pathology (Fig. 1). The patient was consulted to the thoracic surgery department. Spiral computed tomography of thorax demonstrated multiple lymphanenopathies (LAP), approximately $2 \times 2.5 \mathrm{~cm}$ in size. Most of them are detected in paratracheal, prevascular, carinal and subcarinal areas. In addition, a lobulated, soft tissue density lesion measuring $58 \times 27 \mathrm{~mm}$ was observed (conglomerated LAP) starting from the level of the carina and extending to the left hilus of the lung; and surrounding the left main bronchus (Fig. 2). Then, the patient was scheduled for mediastinoscopy guided biopsy. Patient's histopathology was reported as granulomatous inflammation. Department of chest diseases concluded that the patient had tuberculosis, and followed up her as a case with tuberculosis. The patient was treated with antituberculostatic drugs for 9 months. At the end of the treatment, LAPs did not reduce in size, and left thoracotomy, bronchogenic cyst excision and lymph node biopsy were performed in order to investigate the possibility of the presence of different pathologies. Histopathologic evaluation was reported as a bronchogenic cyst and reactive lymphoid hyperplasia. Therefore it was decided to continue antituberculostatic treatment. There was no improvement in vocal cord paralysis at the end of 9-month follow-up. Patients gave informed consent to use of all tests and data for scientific purposes.

\section{Discussion}

Unilateral vocal cord paralysis occurs due to the damage of RLN which innervates the larynx. Patients typically present

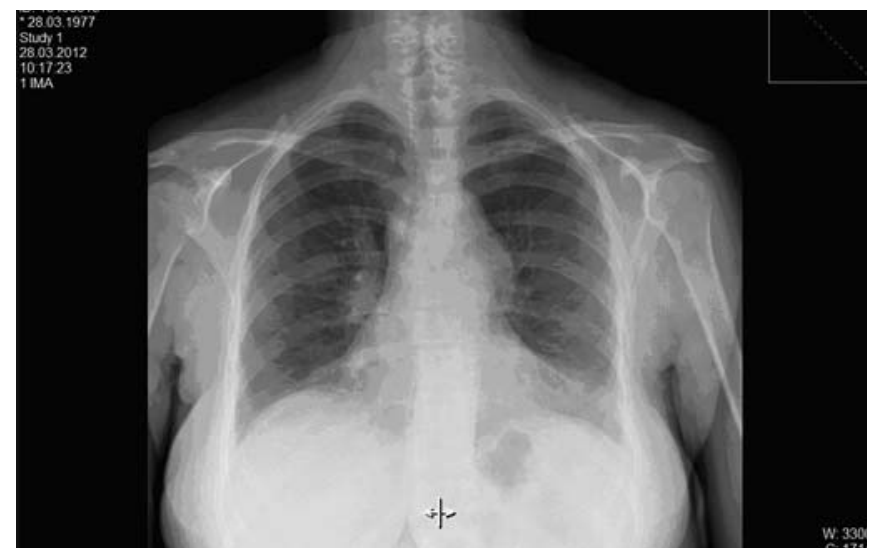

Fig. 1. Chest X-ray of the patient. with peculiar breathy sound because of incomplete closure of the vocal cords. However, they may complaint of aphonia or shortness of breath. Normally, during a conversation, both vocal cords come to the midline and allow the vibration of the vocal cords. ${ }^{[5]}$ In our case, the patient's main complaint was not hoarseness; it was the feeling of fullness and obstruction in the throat. Laryngoscopy should be performed in patients with complaints lasting more than 15 days. In adults, also extralaryngeal causes of vocal cord paralysis effect RLN along its anatomical pathway. In some series, traumatic factors were the most observed causes of unilateral vocal cord paralysis. Thyroid, neck and mediastinal surgery-related injuries, brain injuries and car accidents also cause vocal cord paralysis. Malignant tumors are also regarded as the other reasons of vocal cord paralysis. Thyroid, esophagus, mediastinum and lung cancer-related paralysis are not uncommon. In most series, less than $10 \%$ of the causes was infectious and neurological. Between 10$30 \%$ of the cases, the reason was idiopathic. ${ }^{[1]}$

Physician must follow the course of vagal nerve and RLN from the basis cranii to the mediastinum by CT. Vagal nerve originates from the nucleus ambiguus in the brain and descends along with internal carotid artery and internal jugular vein within the carotid sheath. ${ }^{[5]}$ In our case, when left vocal cord paralysis has been observed, chest $\mathrm{x}$-ray was performed at first and the extension to the mediastinum was found on the left side.

The incidence of mediastinal masses was reported as 4 9/10,000 ${ }^{[3]}$ While investigating the causes of RLN paralysis, malignancies and tuberculosis should be considered in developing countries and in immigrants of the developedindustrialized countries. ${ }^{[4]}$ Fibrosis in chronic pulmonary tuberculosis in upper lobes and scar tissue may affect the

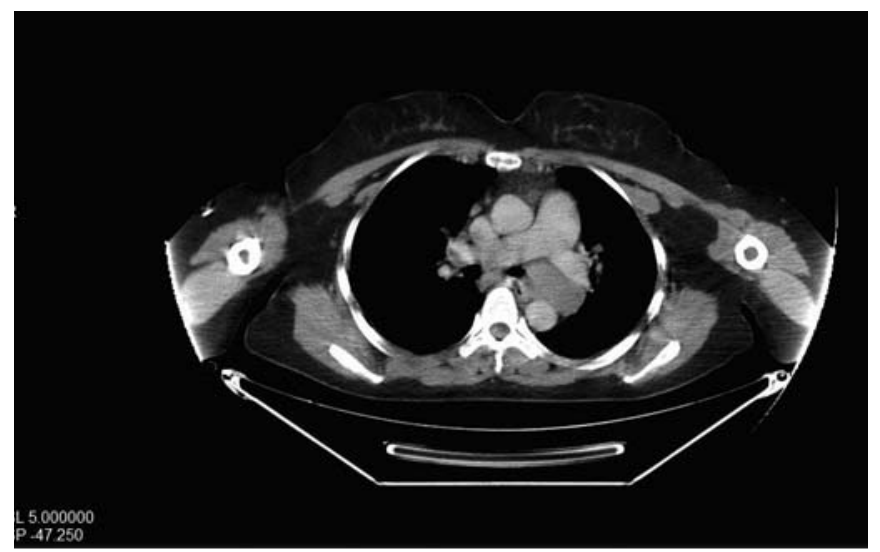

Fig. 2. Computed tomogram of the thorax. 
RLN. ${ }^{[6]}$ It may be related to enlarged tuberculosis nodules or compression on the RLN in scar tissue or fibrosis. ${ }^{[7]}$ Recurrent laryngeal nerve may be damaged due to compression by enlarged tuberculous lymph nodes and anatomical swellings at arteriopulmoner window and aortic arch. Mycobacterium tuberculosis causes tissue necrosis, fibrosis and heals tissue by stimulating T-cell-dependent immune response. On the other hand, Fowler and Hetzel suggested that RLN is affected by emptying of the lymph node abscess rather than mechanical factors. ${ }^{[8]}$ However, Rafay advocated that the damage was related to lymph node compression. ${ }^{[9]}$ Partial recovery of the RLN functions and dysphonia after treatment showed that both mechanical compression and mediastinal fibrosis are effective. ${ }^{[4]}$

In this case, it was concluded that RLN paralysis was developed due to the compression of conglomerated lymph nodes. Therefore, the patient's routine laryngoscopic examination was performed. Laryngeal CT or magnetic resonance imaging will also be planned for this patient during follow-up.

Conflict of Interest: No conflicts declared.

\section{References}

1. Glazer HS, Aronberg DJ, Lee JK, Sagel SS. Extralaryngeal causes of vocal cord paralysis: CT evaluation. AJR Am J Roentgenol 1983;141:527-31.

2. Ko HC, Lee LA, Li HY, Fang TJ. Etiologic features in patients with unilateral vocal fold paralysis in Taiwan. Chang Gung Med J 2009;32:290-6.

3. Yıdız D, Türüt H, Sırmalı M, et al. Mediastinal kitlelerde cerrahi yaklaşım: 142 olgunun değerlendirmesi. Süleyman Demirel Üniversitesi Tip Fakültesi Dergisi 2005;12:1-5.

4. Meral M, Akgun M, Kaynar H, et al. Mediastinal lymphadenopathy due to mycobacterial infection. Jpn J Infect Dis 2004;57:1246.

5. Evans JM, Schucany WG. Hoarseness and cough in a 67-yearold woman. Proc (Bayl Univ Med Cent) 2004;17:469-72.

6. Gupta SK. The syndrome of spontaneous laryngeal palsy in pulmonary tuberculosis. J Laryngol Otol 1960;74:106-13.

7. Radner DB, Snider GL. Recurrent laryngeal nerve paralysis as a complication of pulmonary tuberculosis; a report of two cases. Am Rev Tuberc 1952;65:93-9.

8. Fowler RW, Hetzel MR. Tuberculous mediastinal lymphadenopathy can cause left vocal cord paralysis. Br Med J (Clin Res Ed) $1983 ; 286: 1562$

9. Rafay MA. Tuberculous lymphadenopathy of superior mediastinum causing vocal cord paralysis. Ann Thorac Surg 2000;70: 2142-3.

This is an open access article distributed under the terms of the Creative Commons Attribution-NonCommercial-NoDerivs 3.0 Unported (CC BYNC-ND3.0) Licence (http://creativecommons.org/licenses/by-nc-nd/3.0/) which permits unrestricted noncommercial use, distribution, and reproduction in any medium, provided the original work is properly cited.

Please cite this article as: Dikici O, Bayar Muluk N. Left vocal cord paralysis due to lymphadenopathy of mediastinal tuberculosis. J Med Updates 2013; 3(2):98-100. 